\title{
Peningkatan Kompetensi Guru IPA melalui Pelatihan dan Pendampingan Pembuatan Perangkat dan Media Pembelajaran Berbasis Pendekatan Saintifik
}

\author{
Improving Science Teacher Competence through Training and Assisting in Making Tools and \\ Learning Media Based on Scientific Approach
}

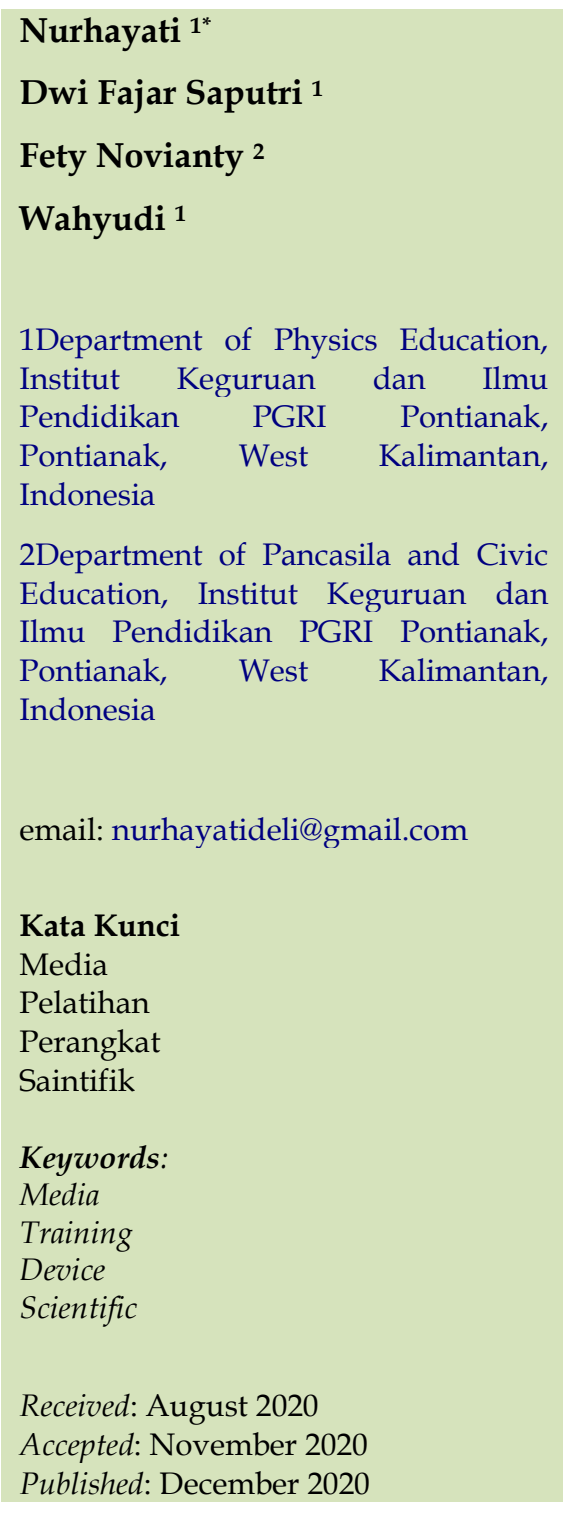

\begin{abstract}
Abstrak
Program Kemitraan Masyarakat (PKM) ini bertujuan untuk menambah pengetahuan dan melatih guru dalam membuat dan mengaplikasikan perangkat pembelajaran berbasis pendekatan saintifik bermuatan karakter dan membuat serta mengaplikasikan media/ alat peraga yang kontekstual dan inovatif dalam pembelajaran. Metode pelaksanan kegiatan PKM terdiri dari sosialisasi, seminar, pelatihan, pendampingan, dan implementasi. Peserta kegiatan PKM yaitu guru-guru IPA SMP sederajat yang tergabung dalam MGMP IPA SMP Kota Singkawang. Hasil kegiatan menunjukkan bahwa (1) guru-guru antusias mengikuti rangkaian kegiatan yang dilaksanakan, (2) guru-guru termotivasi untuk membuat media pembelajaran IPA dan menerapkannya dalam pembelajaran di kelas, dan (3) guru-guru termotivasi untuk membuat dan mengaplikasikan model-model pembelajaran berbasis pendekatan saintifik bermuatan karakter dalam pembelajaran di kelas.
\end{abstract}

\begin{abstract}
This Community Partnership Program (PKM) aims to increase knowledge and train teachers to create and apply learning tools based on scientific approaches that contain the character and create and apply contextual and innovative media/props in learning. The method of implementing PKM activities consists of socialization, seminars, training, mentoring, and implementation. Participants in PKM activities are science teachers of SMP and equivalent who are members of the MGMP IPA of SMP Kota Singkawang. The results of the activity showed that (1) the teachers were enthusiastic about participating in the series of activities carried out, (2) the teachers were motivated to make science learning media and apply them in classroom learning, and (3) the teachers were motivated to create and apply models. a learning model based on a scientific approach that contains a character in classroom learning.
\end{abstract}

(c) 2020 Nurhayati, Dwi Fajar Saputri, Fety Novianty, Wahyudi. Published by Institute for Research and Community Services Universitas Muhammadiyah Palangkaraya. This is Open Access article under the CC-BYSA License (http://creativecommons.org/licenses/by-sa/4.0/).

DOI: https://doi.org/10.33084/pengabdianmu.v6i1.1593

\section{PENDAHULUAN}

Pendidikan merupakan sarana dalam memperoleh ilmu untuk menghadapi kehidupan saat ini maupun kehidupan yang akan datang (Habibah, 2017). Menurut Mulyasa (2011), pendidikan pada hakekatnya merupakan proses pematangan kualitas hidup. Melalui proses tersebut diharapkan manusia dapat memahami 
arti dan hakikat hidup dan berkehidupan secara benar (Khobir, 2010). Untuk mewujudkan hakikat dari pendidikan secara benar, Pemerintah telah mengaturnya dalam Undang-Undang Nomor 20 Tahun 2003 Pasal 3 tentang tujuan pendidikan nasional yang berfungsi untuk mengembangkan kemampuan, membentuk watak dan peradaban bangsa yang bermartabat dalam rangka mencerdaskan kehidupan bangsa, serta memiliki tujuan untuk mengembngkan potensi dari peserta didik agar menjadi manusia yang beriman dan bertakwa kepada Tuhan Yang Maha Esa, berakhlak mulia, sehat, kreatif, mandiri, berilmu, cakap, serta menjadi warganegara yang demokratis serta bertanggung jawab. Pembelajaran adalah proses interaksi dari pendidik terhadap peserta didik untuk mencapai tujuan tertentu. Saefudin dan Berdiati (2014) mengungkapkan bahwa pembelajaran secara harfiah berarti proses belajar. Pembelajaran dapat diartikan sebagai proses penambahan pengetahuan dan wawasan melalui rangkaian aktivitas yang dilakukan seseorang secara sadar dan mengakibatkan perubahan pada dirinya, sehingga terjadi perubahan yang bersifat positif, dan pada tahap akhir akan mendapatkan kecakapan, keterampilan dan pengetahuan yang baru (Herawati, 2018). Menurut Rusman (2017), pembelajaran menjadi suatu sistem yang terdiri dari berbagai komponen yang saling terhubung antara satu dengan yang lain. Komponen tersebut meliputi tujuan, materi, metode dan evaluasi.

Pembelajaran melalui pendekatan saintifik adalah proses pembelajaran yang dirancang sedemikian rupa agar peserta didik secara aktif dapat mengkonstruksi konsep, hukum, atau prinsip melalui tahapan-tahapan mengamati (untuk mengidentifikasi atau menemukan masalah), merumuskan masalah, mengajukan atau merumuskan hipotesis, mengumpulkan data dengan berbagai teknik, menganalisis data, menarik kesimpulan, dn mengomunikasikan konsep, hukum atau prinsip yang ditemukan (Ghozali, 2017). Tujuan pembelajaran dengan pendekatan saintifik, didasarkan pada keunggulan pendekatan tersebut, antara lain: (1) meningkatkan kemampuan intelek, khususnya kemampuan berfikir tingkat tinggi, (2) untuk membentuk kemampuan siswa dalam menyelesaikan suatu masalah secara sistematik, (3) terciptanya kondisi pembelajaran dimana siswa merasa bahwa belajar itu merupakan suatu kebutuhan, (4) diperolehnya hasil belajar yang tinggi, (5) untuk melatih siswa dalam mengomunikasikan ide-ide khususnya dalam menulis artikel ilmiah, dan (6) untuk mengembangkan karakter siswa (Machin, 2014).

Penerapan pendekatan saintifik dalam pembelajaran IPA memerlukan pemahaman konsep serta pengetahuan dalam pemecahan masalah dalam kehidupan yang berkenaan dengan pembelajaran IPA. Karena itu, proses pembelajaran IPA disekolah hendaknya menekankan pada pemberian pengalaman secara langsung untuk mengembangkan kompetensi agar siswa dapat memahami alam disekitar secara ilmiah (Rohmawati et al., 2018). Selain itu, melalui proses pembelajaran penemuan/pengalaman langsung, guru juga dapat mengembangkan karakter positif siswa. Menurut Afrizon et al. (2012), karakter adalah disposisi seseorang yang relatif stabil, yang menjunjung tinggi nilai-nilai etika utama seperti menghargai/ menghormati, bertanggung jawab, jujur, adil dan peduli. Terdapat empat jenis karakter konservasi yang dapat dikembangkan selama proses pembelajaran, yaitu (1) pendidikan karakter berbasis nilai budaya, yang merupakan kebenaran wahyu Tuhan (konservasi moral), (2) pendidikan karakter berbasis budaya, antara lain yang berupa budi pekerti, pancasila, apresiasi sastra, keteladanan tokok-tokoh sejarah dan para pemimpin bangsa (konservasi budaya), (3) pendidikan karakter 
berbasis lingkungan (konservasi lingkungan), dan (4) pendidikan karakter berbasis potensi diri, yaitu sikap pribadi, hasil proses kesadaran pemberdayaan potensi diri yang diarahkan untuk meningkatkan kualitas pendidikan (konservasi humanis) (Leksono et al., 2013).

Hasil wawancara dengan ketua MGMP IPA Kota Singkawang Bapak Saryadi, ST diketahui bahwa guruguru IPA kesulitan dalam membuat dan mengaplikasikan desain pembelajaran dengan model pembelajaran berbasis pendekatan saintifik serta meintegrasikan penanaman karakter dalam pembelajaran IPA. Selain itu, guru-guru masih terbatas dalam menggunakan media/alat peraga dalam membelajarkan konsep IPA. Hal ini disebabkan beberapa faktor diantaranya (1) kurangnya pemahaman guru terkait model-model pembelajaran berbasis pendekatan saintifik bermuatan karakter; (2) banyaknya jam mengajar guru dalam sepekan; dan (3) kurangnya pemahaman guru dalam membuat media/alat peraga IPA sederhana. Hal ini tentu akan berdampak pada proses pembelajaran IPA di kelas. Pembelajaran yang seharusnya terfokus pada siswa menjadi terfokus pada guru. Siswa menjadi tidak terlath untuk mengembangkan kemampuan berpikirnya untuk menemukan materi ataupun konsep IPA.

Mengatasi permasalahan tersebut, maka dilaksanakan pelatihan dan pendampingan guru-guru IPA di Kota Singkawang dalam membuat perangkat dan media pembelajaran IPA berbasis pendekatan saintifik bermuatan karakter. Setelah guru terampil dalam membuat perangkat dan media pembelajaran, kemudian guru dilatih untuk menggunakannya dalam proses pembelajaran.

\section{METODOLOGI}

Kegiatan pengabdian ini merupakan rangkaian kegiatan dari Program Kemitraaan Masyarakat (PKM) Direktorat
Riset dan Pengabdian Masyarakat (DRPM) Kementerian Riset, Teknologi dan Perguruan Tinggi (Ristekdikti) Tahun 2019. Kegiatan PKM ini meliputi sosialisasi, seminar, pelatihan, pendampingan, dan implementasi. Secara rinci metode yang dapat diuraikan adalah sebagai berikut: (1) Sosialisasi kegiatan PKM kepada mitra yaitu Ketua MGMP IPA Kota Singkawang dan Disikbud Kota Singkawang, (2) Seminar Model dan Media Pembelajaran IPA Berbasis Pendekatan Saintifik Bermuatan Karakter, (3) Pelatihan dan pendampingan pembuatan perangkat pembelajaran IPA berbasis pendekatan saintifik bermuatan karakter, (4) Pelatihan dan pendampingan pembuatan media pembelajaran IPA, (5) Implementasi penggunaan perangkat dan media pembelajaran IPA pada tiga SMP di Kota Singkawang oleh tiga orang guru model, (6) Diseminasi dan evaluasi pelaksanaan kegiatan PKM, dan (7) Serah terima media IPA kepada mitra.

\section{HASIL DAN PEMBAHASAN}

Kegiatan pengabdian ini diawali dengan sosialisasi kepada mitra. Hasil sosialisasi diperoleh rincian kegiatan berdasarkan analisis kebutuhan mitra sebagaimana ditunjukkan pada Tabel I.

Tabel I. Rincian Kegiatan Berdasarkan Analisis Kebutuhan Mitra

\begin{tabular}{|c|c|}
\hline Tujuan Kegiatan & Bentuk dan Waktu Kegiatan \\
\hline $\begin{array}{l}\text { Meningkatkan } \\
\text { pemahaman guru IPA } \\
\text { tentang model-model } \\
\text { pembelajaran berbasis } \\
\text { pendekatan saintifik } \\
\text { bermuatan karakter } \\
\text { Meningkatkan } \\
\text { pemahaman guru IPA } \\
\text { tentang macam-macam } \\
\text { media inovatif dalam } \\
\text { pembelajaran IPA } \\
\text { Meningkatkan } \\
\text { keterampilan guru dalam } \\
\text { menyusun perangkat } \\
\text { pembelajaran } \\
\text { berbasis pendekatan } \\
\text { saintifik bermuatan } \\
\text { karakter } \\
\text { Meningkatkan } \\
\text { keterampilan dalam }\end{array}$ & \begin{tabular}{lrr} 
Workshop & \multicolumn{2}{r}{ penyusunan } \\
perangkat dan & media \\
pembelajaran & & berbasis \\
pendekatan & & saintifik \\
bermuatan karakter (22 dan 23 \\
Juli 2019)
\end{tabular} \\
\hline
\end{tabular}




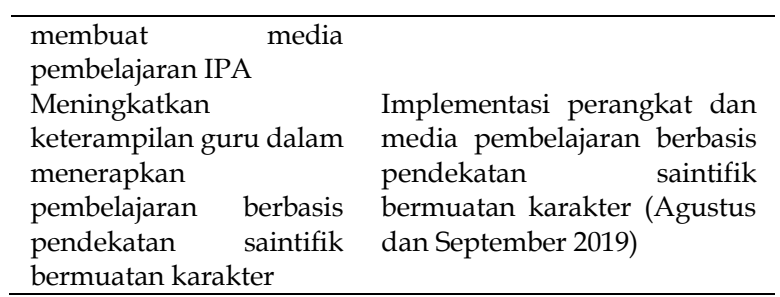

Kegiatan kedua yaitu seminar model dan media pembelajaran IPA berbasis pendekatan saintifik bermuatan karakter. Tujuan kegiatan ini yaitu untuk meningkatkan pemahaman guru tentang model-model pembelajaran inovatif berbasis pendekatan saintifik yang dapat diterapkan dalam pembelajaran IPA SMP, integrasi karakter dalam pembelajaran IPA melalui model-model pembelajaran dan pemanfaatan media pembelajaran IPA.

Kegiatan ketiga yaitu pelatihan dan pendampingan pembuatan perangkat dan media pembelajaran IPA berbasis pendekatan saintifik bermuatan karakter. Kegiatan pelatihan dilaksanakan selama dua hari pada tanggal 22 dan 23 Juli 2019 bertempat di SMP Negeri 20 Singkawang. Tujuan kegiatan ini yaitu untuk meningkatkan keterampilan guru dalam menyusun perangkat pembelajaran berbasis pendekatan santifik bermuatan karakter dan meningkatkan keterampilan guru dalam membuat media pembelajaran IPA sederhana. Kegiatan dibuka oleh Kasi Kurikulum Bidang SMP dan dihadiri oleh guru-guru MGMP IPA Kota Singkawang. Setelah pembukaan, kegiatan diawali dengan penyampaian panduan dalam membuat perangkat dan media pembelajaran. Hal ini dimaksudkan untuk menyamakan persepsi kepada masing-masing kelompok tentang format penyusunan RPP dan LKS.

Pada hari pertama pelatihan, peserta dilatih dan dibimbing oleh tim PKM dalam menyusun perangkat pembelajaran yang meliputi rencana pelaksanaan pembelajaran (RPP) dan lembar kerja siswa (LKS) (Gambar 1). Penyusunan perangkat sesuai dengan materi yang telah disepakati oleh masing-masing kelompok pada pertemuan sebelumnya. Setiap kelompok menyusun RPP untuk tiga pertemuan yang dilengkapi dengan LKS dan instrumen penilaian. Penyusunan RPP diawali dengan penjabaran indikator berdasarkan kompetensi dasar yang telah dipilih oleh masing-masing kelompok. Selanjutnya menentukan model pembelajaran yang berbasis pendekatan saintifik.Setelah menetapkan model pembelajaran, masing-masing kelompok menyusun langkah-langkah pembelajaran berdasarkan langkah-langkah model pembelajaran yang terintegrasi dengan pengembangan karakter siswa. RPP yang telah disusun kemudian dilengkapi dengan LKS. LKS disusun oleh masingmasing kelompok untup tiap pertemuan berbasis model pembelajaran. Adapun sebaran materi RPP dan LKS yang telah dihasilkan dari kegiatan workshop disajikan pada Tabel II.

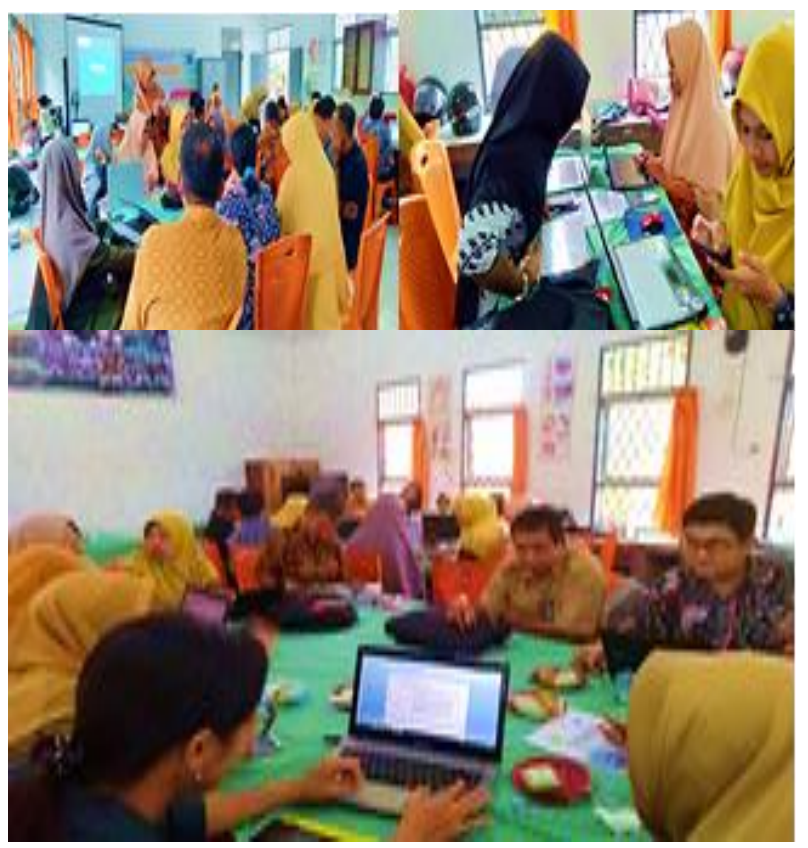

Gambar 1. Diskusi kelompok saat penyusunan perangkat 
Tabel II. Sebaran Materi RPP

\begin{tabular}{|c|c|c|c|c|}
\hline \multirow[b]{2}{*}{ 竎 } & \multirow[b]{2}{*}{ 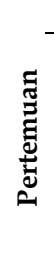 } & \multicolumn{3}{|c|}{ Sub Pokok Materi } \\
\hline & & 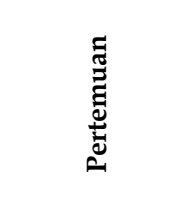 & 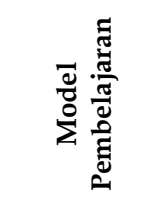 & 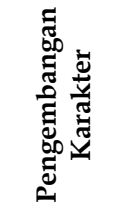 \\
\hline \multirow[t]{3}{*}{$\begin{array}{l}\text { Kelompok } 1 \\
\text { Usaha dan } \\
\text { pesawat } \\
\text { sederhana }\end{array}$} & 1 & Usaha dan daya & $\begin{array}{l}\text { Penemuan } \\
\text { terbimbing }\end{array}$ & $\begin{array}{l}\text { Teliti, } \\
\text { percaya } \\
\text { diri, kerja } \\
\text { sama, } \\
\text { berpikir } \\
\text { kritis dan } \\
\text { kreatif }\end{array}$ \\
\hline & 2 & $\begin{array}{l}\text { Pesawat } \\
\text { sederhana jenis } \\
\text { pengungkit }\end{array}$ & $\begin{array}{l}\text { Penemuan } \\
\text { terbimbing }\end{array}$ & $\begin{array}{l}\text { Teliti, } \\
\text { percaya } \\
\text { diri, kerja } \\
\text { sama, } \\
\text { berpikir } \\
\text { kritis dan } \\
\text { kreatif }\end{array}$ \\
\hline & 3 & $\begin{array}{l}\text { Pesawat } \\
\text { sederhana } \\
\text { bidang miring }\end{array}$ & $\begin{array}{l}\text { Pembelajaran } \\
\text { kooperatif } \\
\text { tipe STAD }\end{array}$ & $\begin{array}{l}\text { Jujur, } \\
\text { tanggung } \\
\text { jawab, } \\
\text { disiplin, } \\
\text { peduli }\end{array}$ \\
\hline \multirow[t]{3}{*}{$\begin{array}{l}\text { Kelompok } 2 \\
\text { Sistem } \\
\text { reproduksi } \\
\text { pada } \\
\text { manusia }\end{array}$} & 1 & Pembelahan sel & $\begin{array}{l}\text { Pembelajaran } \\
\text { kooperatif } \\
\text { tipe STAD }\end{array}$ & $\begin{array}{l}\text { Jujur, } \\
\text { tanggung } \\
\text { jawab, } \\
\text { disiplin, } \\
\text { peduli }\end{array}$ \\
\hline & 2 & $\begin{array}{l}\text { Struktur organ- } \\
\text { organ penyusun } \\
\text { sistem } \\
\text { reproduksi pada } \\
\text { laki-laki dan } \\
\text { perempuan }\end{array}$ & $\begin{array}{l}\text { Penemuan } \\
\text { terbimbing }\end{array}$ & $\begin{array}{l}\text { Teliti, } \\
\text { percaya } \\
\text { diri, kerja } \\
\text { sama, } \\
\text { berpikir } \\
\text { kritis dan } \\
\text { kreatif }\end{array}$ \\
\hline & 3 & $\begin{array}{l}\text { Spermato- } \\
\text { genesis, } \\
\text { oogenesis, dan } \\
\text { siklus } \\
\text { menstruasi }\end{array}$ & $\begin{array}{l}\text { Pembelajaran } \\
\text { kooperatif } \\
\text { tipe STAD }\end{array}$ & $\begin{array}{l}\text { Jujur, } \\
\text { tanggung } \\
\text { jawab, } \\
\text { disiplin, } \\
\text { peduli }\end{array}$ \\
\hline \multirow[t]{3}{*}{$\begin{array}{l}\text { Kelompok } 3 \\
\text { Kasifikasi } \\
\text { makhluk } \\
\text { hidup }\end{array}$} & 1 & $\begin{array}{l}\text { Ciri-ciri } \\
\text { makhluk hidup }\end{array}$ & $\begin{array}{l}\text { Pembelajaran } \\
\text { kooperatif } \\
\text { Jigsaw }\end{array}$ & $\begin{array}{l}\text { Tanggun } \\
\text { g jawab, } \\
\text { percaya } \\
\text { diri, } \\
\text { santun }\end{array}$ \\
\hline & 2 & $\begin{array}{l}\text { Klasifikasi } \\
\text { makhluk hidup }\end{array}$ & $\begin{array}{l}\text { Penemuan } \\
\text { terbimbing }\end{array}$ & $\begin{array}{l}\text { Teliti, } \\
\text { percaya } \\
\text { diri, kerja } \\
\text { sama, } \\
\text { berpikir } \\
\text { kritis dan } \\
\text { kreatif }\end{array}$ \\
\hline & 3 & $\begin{array}{l}\text { Klasifikasi } \\
\text { tumbuhan }\end{array}$ & $\begin{array}{l}\text { Pembelajaran } \\
\text { kooperatif } \\
\text { tipe STAD }\end{array}$ & $\begin{array}{l}\text { Jujur, } \\
\text { tanggung } \\
\text { jawab, } \\
\text { disiplin, } \\
\text { peduli }\end{array}$ \\
\hline
\end{tabular}

Pada hari kedua tanggal 23 Juli 2019, dilaksanakan pelatihan dan pendampingan pembuatan media/alat peraga dalam pembelajaran IPA. Media yang dibuat terdiri dari pesawat sederhana, kartu pembelahan sel (KM2), papan sistem reproduksi pada manusia, media oogenesis, kartu ciri-ciri makhluk hidup, video klasifikasi makhluk hidup, dan kartu hewan dan tumbuhan.
Tampak pada saat pembuatan media, masing-masing kelompok mengeluarkan ide-ide kreatif dalam membuat media (Gambar 2). Hal ini ditunjukkan dari hasil media yang telah dibuat tiap kelompok.

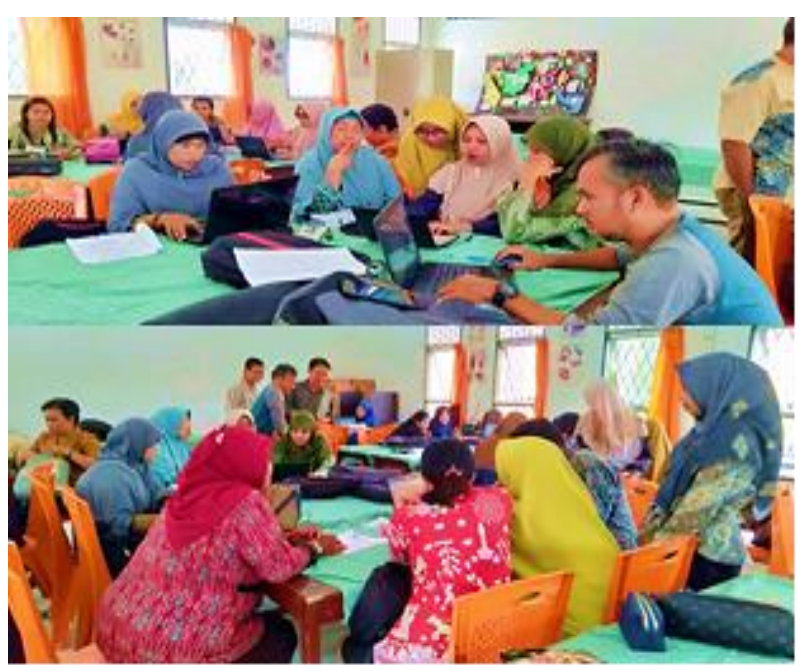

Gambar 2. Diskusi Kelompok saat pembuatan media

Hasil penyusunan perangkat dan media pembelajaran yang telah dibuat, kemudian dipresentasikan di depan oleh tiap-tiap kelompok (Gambar 3). Hal ini bertujuan agar semua peserta dapat memperoleh pengetahuan dan informasi terkait penyusunan perangkat dan media yang telah dibuat oleh semua kelompok.

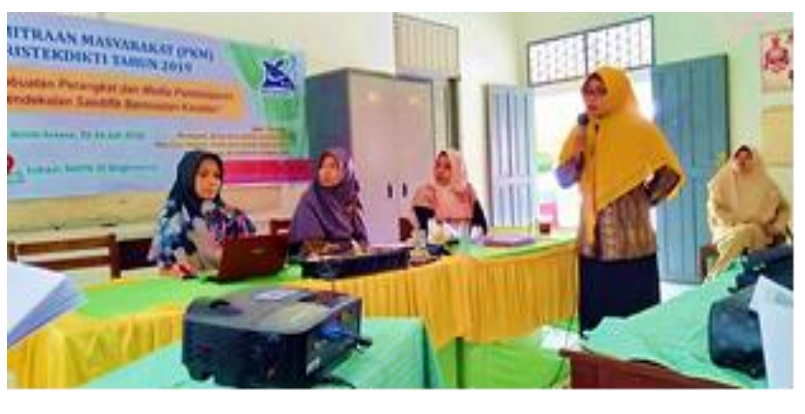

Gambar 3. Presentasi Kelompok

Tim PKM juga memberikan penilaian terkait perangkat dan media pembelajaran yang telah dibuat berdasarkan presentasi tiap kelompok. Berdasarkan hasil penilaian tim, diperoleh 2 kelompok dengan predikat terbaik dalam penyusunan perangkat (RPP dan LKS) yaitu kelompok3A dan kelompok 2C dan 1 kelompok dengan predikat terbaik dalam pembuatan media yaitu 
kelompok 2A. Masing-masing kelompok terbaik mendapatkan doorprize dari tim pelaksana PKM (Gambar 4).

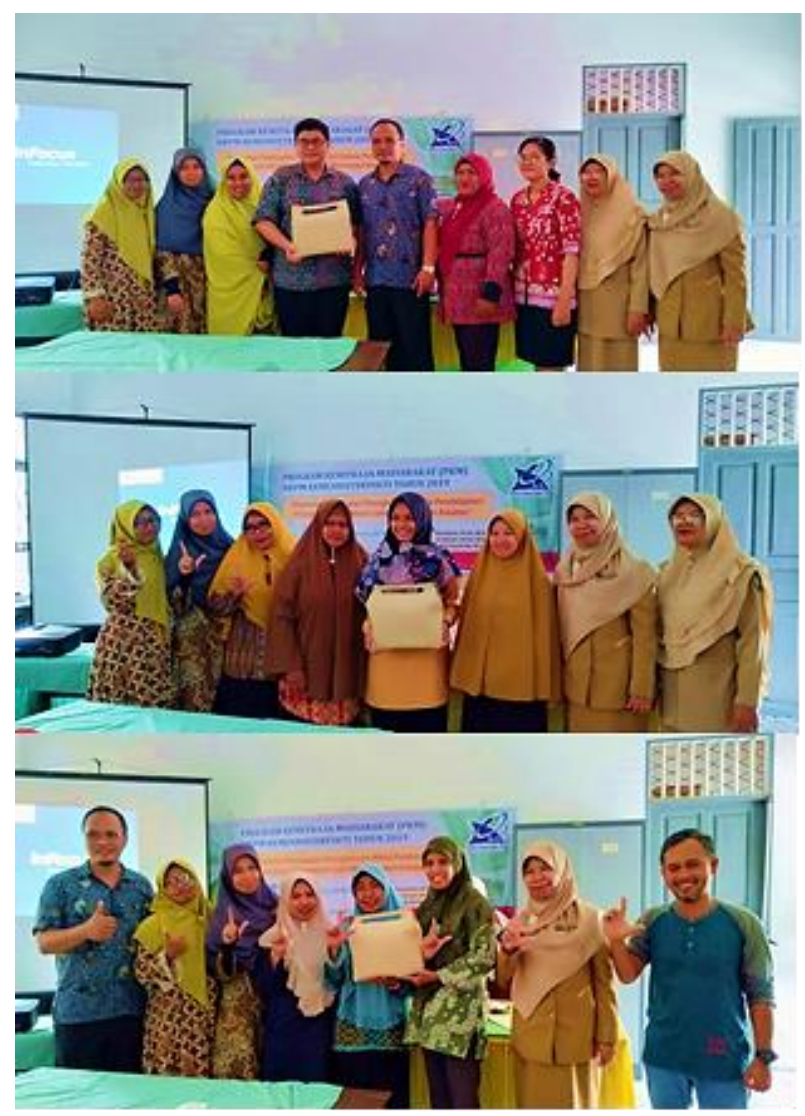

Gambar 4. Foto bersama kelompok terbaik

Kegiatan selanjutnya yaitu penentuan tiga guru model untuk tiap kelompok besar dan penentuan jadwal pelaksanaan implementasi perangkat dan media yang telah dibuat dalam pembelajaran di kelas. Hasil diskusi bersama guru-guru disepakati tiga guru model yaitu Ibu Fitri Kurniati, S.Pd, M.Pd. untuk kelompok 1, Ibu Lorentina Elsi, M.Pd. untuk kelompok 2, dan Bintari Dwidianti, S.Pd. untuk kelompok 3. Pelaksanaan implementasi disepakati pada tanggal 8 Agustus $2019 \mathrm{di}$ SMP Torsina 1 Singkawang, implementasi kedua pada tanggal 2 September 2019 di SMPN 3 Singkawang dan implementasi ketiga pada tanggal 3 September 2019 di SMPN 9Singkawang.

Secara umum, hasil yang diperoleh dalam kegiatan ini yaitu perangkat pembelajaran yang terdiri dari RPP, LKS dan instrumen penilaian untuk tiga materi pokok dengan jumlah masing-masing 3 pertemuan serta media pembelajaran untuk tiap pertemuan.

Kegiatan keempat yaitu implementasi perangkat pembelajaran dan media/alat peraga yang telah didesain oleh masing-masing kelompok dalam pembelajaran di kelas. Implementasi pertama dilaksanakan di SMP Torsina 1 Singkawang oleh guru model Ibu Lorentia Elsi, S.Pd pada tanggal 8 Agustus 2019. Sebelum guru model melaksanakan pembelajaran sesuai dengan perangkat dan menggunakan media yang dibuat, terlebih dahulu dilakukan breafing bersama observer dalam rangka menyamakan persepsi dan pembagian tugas dalam mengobservasi proses pembelajaran (Gambar 5). Pertemuan pertama berlangsung $3 \mathrm{jp}$ dengan durasi waktu 120 menit (Gambar 6). Setelah pembelajaran dilaksanakan, dilanjutkan dengan refleksi guna memaparkan hasil temuan saat observasi (Gambar 7). Melalui hasil temuan tersebut akan diketahui kelemahan dan kelebihan dari pembelajaran yang telah dilaksanakan. Hasil temuan menunjukkan bahwa terdapat beberapa siswa yang belum tampak mampu bekerjasma di dalam tim karena kurangnya kepercayaan bersama tim, untuk itu pada pertemuan kedia disarankan mengganti anggota kelompok tersebut. Selain itu, karena sumber belajar siswa masih kurang, maka disarankan untuk membuat modul pembelajaran yang berisi tentang materi yang akan diajarkan.

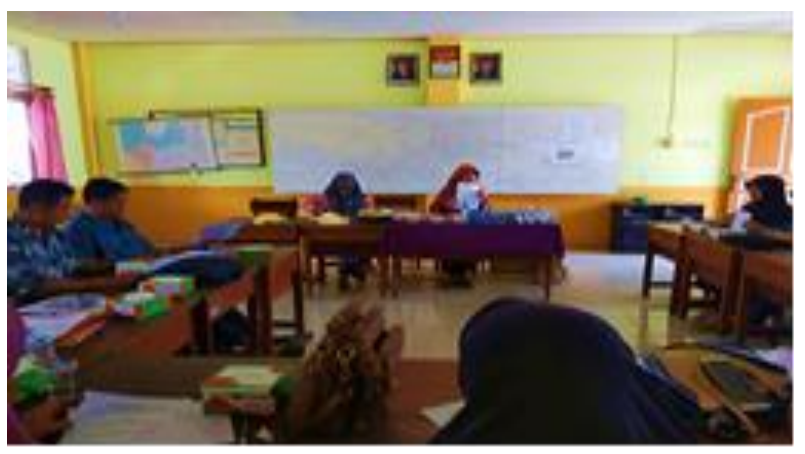

Gambar 5. Breafing sebelum pelaksanan open class 


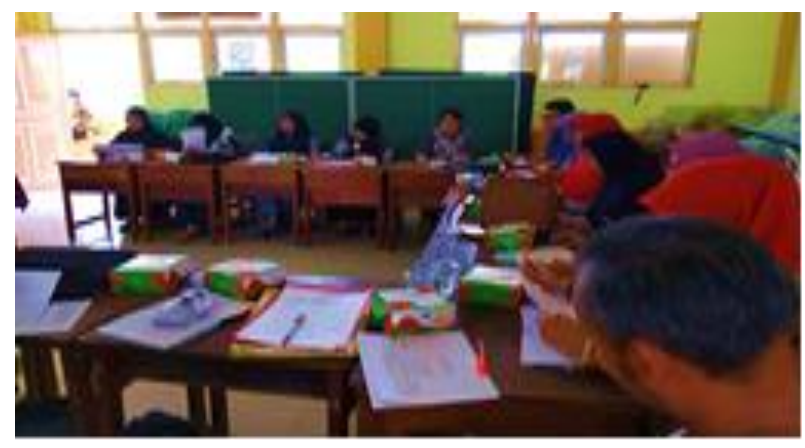

Gambar 6. Evaluasi dan Refleksi setelah pelaksanan open class

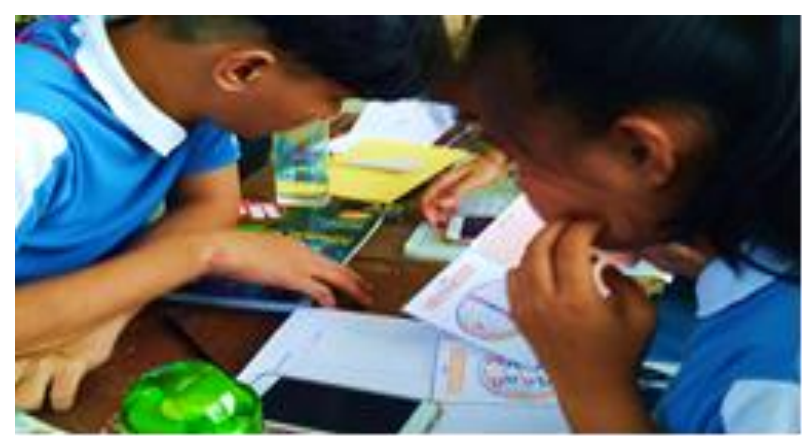

Gambar 7. Pelaksanan open class

Implementasi kedua dilaksanakan di SMPN 3 Singkawang oleh guru model Ibu Fitri Kurniati, S.Pd, M.Pd pada tanggal 2 September 2019. Pelaksanaan pembelajaran di kelas VIII E materi pesawat sederhana (usaha dan energi) selama 2jp (2x40 menit). Berdasarkan hasil pengamatan saat pembelajaran, siswa terlihat aktif dengan yel-yel kelas dan kelompok. Hampir sebagian besar siswa mengikuti proses pembelajaran dengan sungguh-sungguh. Hal ini terlihat dari banyaknya siswa yang bertanya dan menjawab pertanyaan yang diajukan oleh guru. Selain itu, pada saat siswa diminta berdiskusi menyelesaikan LKS, siswa secara sigap mengumpulkan data dalam penyelesaian LKS (Gambar 8).

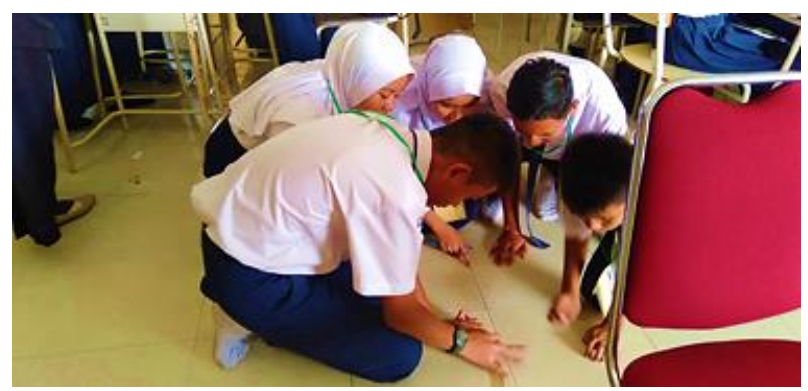

Gambar 8. Pengumpulan Data LKS yang dilakukan secara berkelompok
Implementasi ketiga dilaksanakan di SMPN 9 Singkawang oleh guru model Ibu Bintari Dwidianti, S.Pd. Pelaksanaan pembelajaran di kelas VI A materi klasifikasi makhluk hidup selama 2 jp (2x40 menit). Temuan yang diperoleh dari pengamatan diantaranya (1) siswa kelihatan tegang mengikuti pembelajaran dikarenakan banyak observer yang ada di dalam kelas, dan hal ini merupakan pengalaman pertama bagi siswa; (2) waktu pembelajaran lebih efektif dengan adanya pengaturan waktu baik diskusi maupun pengerjaan tugas; (3) siswa masih kebingungan dalam pembagian kelompok ahli dan asal karena model ini baru diterapkan dalam kelas; (4) siswa terlihat lebih santai dan semangat ketika pengerjaan tugas kelompok menggunakan media kartu dan papan magnet (Gambar 9).

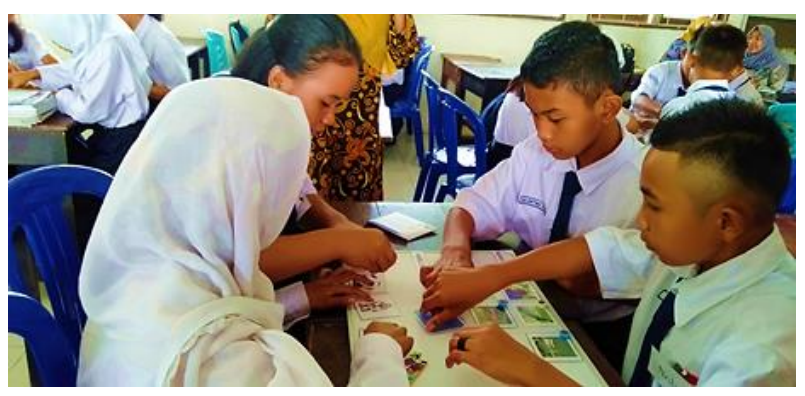

Gambar 9. Pengerjaan LKS yang dilakukan secara berkelompok

Berdasarkan temuan tersebut, pada saat refleksi ada beberapa hal yang disarankan yaitu: (1) perlu adanya penyampaian teknik penilaian dan langkah-langkah pembelajaran yang akan dilakukan; dan (2) perlu penggunaan media pembelajaran yang dapat menarik perhatian siswa di awal pembelajaran.

Kegiatan kelima yaitu diseminasi dan evaluasi pelaksanaan kegiatan PKM sekaligus penyerahan barang berupa media pembelajaran kepada mitra. Pada saat diseminasi disampaikan deskripsi hasil implementasi yang telah dilaksanakan (Gambar 8). Kegiatan ini dihadiri oleh Kasi Kurikulum SMP Disdiknas Kota Singkawang Ibu Anita Wijayanti, M.Si yang sekaligus menutup kegiatan PKM. 


\section{KESIMPULAN}

Kegiatan Program Kemitraan Masyarakat yang dilakukan oleh tim Pengabdi IKIP PGRI Pontianak bersama mitra MGMP IPA SMP Kota Singkawang secara keseluruhan terlaksana dengan baik. Peserta PKM yaitu guru-guru IPA SMP sederajat yang tergabung dalam MGMP IPA Kota Singkawang antusias dalam mengikuti rangkaian kegiatan PKM. Mereka tertarik untuk membuat media pembelajaran IPA dan termotivasi untuk mencoba menggunakannya dalam pembelajaran IPA di sekolah.

\section{UCAPAN TERIMA KASIH}

Terima kasih kepada Ditjen Penguatan Riset dan Pengembangan Kementerian Riset dan Teknologi atas dana Program Kemitraan Masyarakat tahun 2019 dan IKIP PGRI Pontianak yang telah memfasilitasi sehingga kegiatan pengabdian ini dapat dilaksanakan.

\section{REFERENSI}

Afrizon, R., Ratnawulan, R., Fauzi, A. 2012. peningkatan perilaku berkarakter dan keterampilan berpikir kritis siswa kelas ix mtsn model padang pada mata pelajaran ipa-fisika menggunakan model problem-based instruction. Jurnal Penelitian Pembelajaran Fisika (JPPF). 1(1):1-16. https://doi.org/10.1234/jppf.v1i1.598

Ghozali, A. 2017. Pendekatan Scientific Learning Dalam Meningkatkan Prestasi Belajar Siswa. Pedagogik : Jurnal Pendidikan. 4(1):1-13. https://doi.org/10.33650/pjp.v4i1.5

Habibah, S. 2017. Implikasi Filsafat Ilmu terhadap Perkembangan Ilmu Pengetahuan dan Teknologi. Dar-eL-Ilmi: Jurnal Studi Keagamaan, Pendidikan dan Humaniora. 4(1):166-180.

Herawati, H. 2018. Memahami Proses Belajar Anak. Bunayya: Jurnal Pendidikan Anak. 4(1):27-48.
Khobir, A. 2010. Hakikat Manusia Dan Implikasinya Dalam Proses Pendidikan (Tinjauan Filsafat Pendidikan Islam). Forum Tarbiyah. 8(1):1-15.

Leksono, S.M., Rustaman, N., Redjeki, S. 2013. Kemampuan Profesional Guru Biologi Dalam Memahami Dan Merancang Model Pembelajaran Konservasi Biodiversitas Di SMA. Cakrawala Pendidikan. 32(3):408-419. https://doi.org/10.21831/cp.v3i3.1628

Machin, A. 2014. Implementasi Pendekatan Saintifik, Penanaman Karakter Dan Konservasi Pada Pembelajaran Materi Pertumbuhan. Jurnal Pendidikan IPA Indonesia. 3(1):28-35. https://doi.org/10.15294/jpii.v3i1.2898

Mulyasa, D. 2011. Pendidikan Bermutu dan Berdaya Saing. Bandung: Remaja Rosdakarya

Rohmawati, S., Sihkabuden, S., Susilaningsih, S. 2018. Penerapan Pendekatan Saintifik Pada Mata Pelajaran IPA Di MTS Putri Nurul Masyithoh Lumajang. JKTP: Jurnal Kajian Teknologi Pendidikan. 1(3):205-212.

Rusman. 2017. Belajar dan Pembelajaran Berorientasi Standar Proses Pendidikan. Jakarta: Kencana

Saefuddin, A., Berdiati, I. 2014. Pembelajaran Efektif. Bandung: Remaja Rosdakarya 